
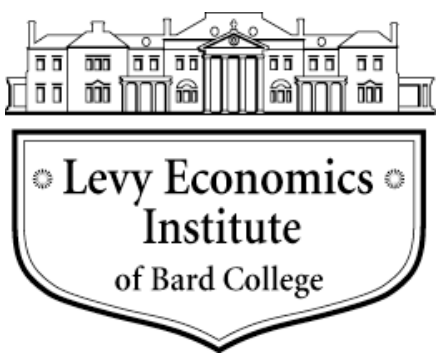

Working Paper No. 772

\title{
Reorienting Fiscal Policy: A Critical Assessment of Fiscal Fine-Tuning
}

by

\author{
Pavlina R. Tcherneva* \\ Levy Economics Institute of Bard College
}

August 2013

* The author gratefully acknowledges financial support through a grant from the Institute for New Economic Thinking (INET).

The Levy Economics Institute Working Paper Collection presents research in progress by Levy Institute scholars and conference participants. The purpose of the series is to disseminate ideas to and elicit comments from academics and professionals.

Levy Economics Institute of Bard College, founded in 1986, is a nonprofit, nonpartisan, independently funded research organization devoted to public service. Through scholarship and economic research it generates viable, effective public policy responses to important economic problems that profoundly affect the quality of life in the United States and abroad.

\author{
Levy Economics Institute \\ P.O. Box 5000 \\ Annandale-on-Hudson, NY 12504-5000 \\ http://www.levyinstitute.org
}

Copyright (C Levy Economics Institute 2013 All rights reserved

ISSN 1547-366X 


\begin{abstract}
The present paper offers a fundamental critique of fiscal policy as it is understood in theory and exercised in practice. Two specific demand-side stabilization methods are examined here: conventional pump priming and the new designation of fiscal policy effectiveness found in the New Consensus literature. A theoretical critique of their respective transmission mechanisms reveals that they operate in a trickle-down fashion that not only fails to secure and maintain full employment but also contributes to the increasing postwar labor market precariousness and the erosion of income equality. The two conventional demand-side measures are then contrasted with the proposed alternative - a bottom-up approach to fiscal policy based on a reinterpretation of Keynes's original policy prescriptions for full employment. The paper offers a theoretical, methodological, and policy rationale for government intervention that includes specific directemployment and investment initiatives, which are inherently different from contemporary hydraulic fine-tuning measures. It outlines the contours of the modern bottom-up approach and concludes with some of its advantages over conventional stabilization methods.
\end{abstract}

Keywords: Full Employment; Fiscal Policy; Aggregate Demand; Business Cycles; Income Distribution; New Consensus

JEL Classifications: E24, E25, E62, E63, J68 


\section{INTRODUCTION}

Every decade or two, in a bout of soul-searching, economists ask themselves whether they are Keynesian or not. For a profession that keeps rediscovering its "Keynesianism" in a policy environment that always exercises some form of fiscal activism, this is surely the wrong question. A more pertinent question would be not whether we are all Keynesians, but why we are so bad at it.

Part of the answer lies in the theoretical developments since the problematic SamuelsonHicks-Hansen interpretation of John Maynard Keynes's work. Part of it rests within the deeply flawed understanding of what shape and form Keynesian fiscal policy must take, the assumed transmission mechanisms for its effectiveness, and the manner in which it is usually executed as a practical matter. This paper deals with the latter set of problems and develops a critical assessment of contemporary fiscal measures.

There have been clear winners and losers from fiscal policy action throughout the $20^{\text {th }}$ century. The advent of what Hyman P. Minsky (1986) called Big Bank and Big Government made depressions in the postwar period virtually impossible. Most nations (especially in the developed world) no longer experience severe and protracted depressions, yet the postwar period has been plagued by milder and much more frequent downturns. ${ }^{1}$ The lender- and spender-oflast-resort functions of central banks and fiscal authorities have provided a floor to collapsing asset prices and aggregate demand. Government action swiftly stabilizes and increases firm profits and cash flows but continuously and consistently fails to produce and maintain full employment. In the words of Minsky (1986), while public policy ensures that the sky does not fall, it has failed to eradicate the haunting terror of unemployment and the widening income gap.

Unemployment and income inequality were the very problems that Keynes proposed to remedy in the 1930s through fiscal policy. Yet, more than 70 years of fiscal activism have not been able to resolve what he called "the two outstanding faults of economic society" (Keynes [1936]1964, p. 327). Worse, as this paper will argue, the manner in which stabilization fiscal policy has been implemented throughout the entire postwar period has itself contributed to the disturbing developments in income distribution and labor markets.

\footnotetext{
${ }^{1}$ In the U.S. for example, depressions occurred on average every 20 years $(1819,1837,1857,1873,1893$, 1907, and 1929). After the Great Depression, recessions dominated the business cycle, causing a downturn on average every 7 years or so $(1937,1945,1953,1957,1960,1969,1973,1978,1980,1982,1990,2001$, and 2007).
} 
In the postwar era short-term unemployment as a share of total unemployment has been on a secular decline. By contrast, long-term unemployment has experienced a ratchet effect: a greater and greater number of people who become unemployed stay in forced idleness for longer and longer periods of time. During every postwar recession, the share of long-term unemployment in total unemployment outpaces its previous peaks and during most expansions it fails to reach its previous lows (Tcherneva 2012a). Important structural shifts in the labor market have contributed to these trends, but fiscal policy has not been able to redress them. The Great Recession witnessed the largest loss in full-time employment in history. Yet, despite a considerable fiscal stimulus, the employment picture has improved only marginally and largely due to the mass exodus of workers from the labor force. Simultaneously, the U.S. employmentpopulation ratio has dropped to a three-decade low, real incomes have stagnated, and income inequality, which had been eroding over the last few decades, has been worsening even during the recovery (ibid.).

The Great Recession has been neither mild nor short; but it has not been a full-fledged depression either. It is the culmination of many cyclical and structural postwar developments and the manifestation of a failed policy approach. The relatively disappointing results from fiscal stabilization efforts around the world have swung the pendulum in the opposite direction - away from countercyclical stabilization and toward pro-cyclical austerity. Fiscal policy is in crisis.

In this context, the present paper asks a foundational question: what shape and form must fiscal policy take to generate long-run full employment, more equitable income distribution, sustainable growth, and better socio-economic outcomes? To answer it, the paper offers a theoretical reassessment of two specific fiscal policy measures commonly invoked in the literature and their respective transmission mechanisms in order to evaluate their relative effectiveness. The first is the conventional aggregate demand management approach (or pump priming) that finds its intellectual lineage in the Neoclassical Synthesis. The second is the contemporary formulation of fiscal policy effectiveness found in the New Consensus literature. Both, it will be argued, operate in a trickle-down fashion because of their transmission mechanisms and the manner in which they aim to produce growth and employment.

These two approaches will be then contrasted with the proposed alternative-a bottom-up approach to fiscal policy that reinterprets some of the original contributions of Keynes and maps out a method for government policy intervention (Tcherneva 2012b). The paper offers a 
theoretical, methodological, and policy rationale for this method à la Keynes that includes specific direct employment and investment initiatives, which are inherently different from contemporary hydraulic fine-tuning measures. The contours of what the modern Keynesian bottom-up policy might look like will be outlined here. The paper concludes with some of the advantages of the bottom-up approach over conventional fine-tuning and suggests a policy design that incorporates full employment, environmental sustainability, and public stewardship, as sensible cardinal measures for fiscal policy effectiveness.

\section{FISCAL POLICY RESURRECTED?}

In economics, the theoretical support for fiscal policy effectiveness has waxed and waned over the decades (Snowdon and Vane 2005). Although Keynes provided the raison d'être for government action in the General Theory (1936), the profession failed to seize the full import of his theoretical contributions and gradually rejected his conclusions. The Ricardian Equivalence Hypothesis was developed to reinforce the claim that fiscal policy has no place in macroeconomic stabilization (Barro 1974, Lucas 1972, Sargent and Wallace 1976).

Nevertheless, in recent years the mainstream has resurrected, albeit reluctantly, a limited role for fiscal policy (e.g., Bernanke 2002, Blinder 2004, Woodford 2003, Wren-Lewis 2000). The policy implications of the new theoretical developments in the mainstream are peculiar. Fiscal policy is still considered to be distortionary and inflationary, but those deficiencies (it is now believed) can be exploited in extreme deflationary periods to produce growth and inflation (Woodford 2003). By contrast, Post-Keynesians, Institutionalists, Feminists, and other heterodox approaches have always theorized an important role for government fiscal measures, but have nevertheless tacitly embraced some of the contemporary aggregate demand management policies that will be subject to critique here.

Despite academia's uneasy relationship with the role and place of fiscal policy, in practice, government spending and taxation are among the first policy levers used to deal with recessions. Using National Income and Product Accounts (NIPA) data we can empirically verify that in the postwar period fiscal policy has been relatively successful in stabilizing growth and profits (Minsky 1986, Tcherneva 2012a), but its impact on employment, income distribution, and public investment has been poor. Furthermore, a steady devolution of services from the federal to 
the state level over the last four decades has resulted in an overall decline in the provisioning of essential public goods and services, exacerbating what John Kenneth Galbraith once called "private opulence in the midst of public squalor" (Galbraith 1958).

The conventional fiscal policies of choice have themselves fostered this state of affairs and helped worsen the income distribution, while failing to maintain tight full employment. To be sure, the contributions of Keynes, Michał Kalecki and Minsky, among others, have clearly demarcated the need for fiscal policy intervention. After all, in the aggregate, government spending has an immediate impact on cash flows, balance sheets, and profits. But the type and direction of government spending determines the specific income and employment-creation effects of each fiscal policy alternative. The employment-creation effects in particular were the cardinal measure identified by Keynes in all of his writings for adjudicating among different fiscal policies (Kregel 2008). As Minsky put it:

[T] he issues in economic theory and policy that we should have to face are not about the ability of prodigious government deficit spending to halt even a very sharp recession but about the relative efficiency of specific measures and the size and aftereffects associated with particular policy strategies. Given the proven power of the deficits of Big Government, the overriding policy issue really should be the determination of the structural effects and objectives of government action. Once government is big, it must be concerned not only with aggregates but with for whom to produce, how to produce, and what kind of output to produce. (Minsky 1986, pp. 21-22)

In this context, the question becomes which types of policy interventions have distinct advantages over others. By reconsidering the approach to fiscal policy in general, we can provide a new perspective on important policy issues that do not narrowly focus on the problems of the Great Recession, but instead use the evidence from the current downturn to propose a more effective conduct of fiscal policy throughout any phase of the business cycle-deceleration, contraction, recovery, or boom. Developing a deeper theoretical and empirical understanding of fiscal policy effectiveness can provide answers to pressing contemporary questions such as: what responsibility does policy bear for the disturbing trends in labor markets and income distribution over the last few decades? Are the current fiscal measures able to guarantee a sustainable recovery? Is there better use of public funds in stabilizing an unstable economy? Why has fiscal policy been so slow to improve the employment situation? Is the latter a problem of little or inappropriate government spending or both? If the direction of spending matters, what kinds of fiscal stimuli can deliver more "bang for the buck?" Are there specific policy measures that can 
address the deep structural problems in labor markets that have been brewing for decades? Are there alternative fiscal policies that generate better income distribution? While the present paper does not provide comprehensive answers to all of these questions, by rethinking the theoretical underpinning of fiscal policy activism in general, it lays the foundations for a new approach to government stabilization policy.

The remainder of the article will examine the transmission mechanisms of fiscal policy intervention that are embodied in the ISLM and New Consensus approaches and contrast them with a proposed bottom-up approach to policy based on a reinterpretation of the original Keynesian recipe for government intervention. The new approach fundamentally reorients policy away from the conventional aggregate demand approach toward a targeted demand approach with a superior automatic stabilizer that aims to narrow, not an ambiguous demand gap for output, but a very clearly defined demand gap for labor, in a manner that produces measurable socioeconomic outcomes.

\section{FISCAL FINE-TUNING: TWO FAILED DEMAND-SIDE TRICKLE-DOWN POLICIES}

Trickle-down fiscal policies are normally associated with the familiar supply-side mechanism that works through reductions in the top marginal tax rates (e.g., Buiter, Persson, and Minford 1985; Canton, Joines, and Laffer, 1983; Henderson 1989). It can be argued however that conventional demand-side alternatives to macroeconomic stabilization also function in a trickledown fashion. Two such demand-side policies can be identified along with the channels through which they are theorized to work. These are: (1) "pump priming" or "conventional aggregate demand management" and (2) the New Consensus fiscal policies, which have emerged from Michael Woodford's Fiscal Theory of the Price Level and Ben Bernanke's work on the 90s Japanese deflation. Both approaches suffer from considerable limitations, two of which are the

erosion of the income distribution and the failure to attain and maintain full employment over the long run.

\subsection{Aggregate Demand Management (Priming the Pump)}

Aggregate demand management essentially works through the familiar Okun's Law mechanism (e.g., Okun 1962). The model relies on priming the economic pump, so that spending starts 
flowing through the economy, producing the requisite growth and employment effects. Note that this approach primarily aims to produce investment-led growth, whereas any resulting employment effect is a bi-product of the pro-growth strategy. The unemployment level is considered to be market-determined and no attempt is made to achieve tight full employment. This is because the profession now believes that there is a non-accelerating inflation rate of unemployment (NAIRU) limit to macroeconomic stabilization policy.

A qualified critique of the trickle-down demand management approach is necessary because it has some immediate advantages: it provides a floor to falling aggregate demand and improves cash flows and balance sheets (Minsky 1986). This approach is quasi-Keynesian because it does not originate from Keynes's own work (more below), but was born out of the flawed early ISLM interpretation of Keynes's theory, developed by Alvin Hicks, John Hansen, and Paul Samuelson. Priming the pump operates on top of a specific economic structure that translates broad-based macro-demand from fiscal policy into specific demands for specific products, produced in specific communities, by specific labor markets and workers. It is only by chance that aggregate expenditures would be such that they would trickle down in the form of enough number of jobs in the right places for all of those who need them, at high enough wages to support all workers and their dependents (Minsky 1965, p. 177).

In short, it is a trickle-down policy, because its transmission mechanism works from aggregate demand of output to specific demand for workers, from profits to wages, and from growth to employment. Job creation is the very last step of the transmission mechanism - an aftereffect of a pro-growth pro-investment policy.

It is also a trickle-down policy because (1) it favors the capital share of income over the labor share and (2) it improves incomes of high-wage/high-skill workers first and lowwage/low-skill workers last, ultimately failing to trickle all the way down to the bottom, in the form income from jobs for the poorest of the poor. There are two main channels through which the pump-priming mechanism works - both of which contribute to the increase in income inequality and prevent it from securing tight full employment. They are (1) the channel for financing of capital assets and investments and (2) the heterogeneous labor markets channel. The first channel works through boosting profits. The anticipation is that improved firm profitability will create the conditions for greater investment and therefore greater employment. However, priming the pump through such a trickle-down demand management policy (from 
profits to jobs) aggravates inequality between the capital and labor shares of income. Conventional pro-growth/pro-investment aggregate demand policies traditionally include investment tax credits, accelerated depreciation, direct contracts with guaranteed profits, and other policies, which directly favor capital incomes. As Minsky argued, high capital incomes result in a revaluation and appreciation of asset prices and the widespread realization of capital gains, which reinforce the financing of capital assets and investments, thereby boosting capital incomes. And since capital income is more unevenly distributed than labor income, these practices worsen overall inequality further (Minsky 1973, pp. 93-95). Additionally, such progrowth pro-investment pump-priming policies never ensure as close an approximation to full employment as is possible, mainly due to liquidity preference and the subjective factors that Keynes outlined in his analysis of unemployment as a monetary phenomenon (more below). Additionally, private employers tend to consider some workers as unemployable (even if they are ready, willing and able to work) — either because they have limited education, skills, and work experience, or because they have a criminal record, or some race, age, gender or other characteristic which they may use to discriminate against them. The private sector's overriding objective, after all, is to extract monetary profit, not to provide jobs for all or to secure and maintain true full employment over the long run.

The task then for designing supplementary policies that would help produce and sustain full employment falls on governments. But it is not only sufficient to recognize that unemployment is a monetary phenomenon and that the private sector as a whole is unable to achieve the macroeconomic objective of full employment. It is also important to acknowledge that conventional aggregate demand policies ignore the structure of the economy and how the income shares are generated, and tend to favor rentier incomes, profits, and high wage workers, therefore bankrolling the very processes that generate income inequality between factor incomes, within labor income, and within capital income.

The second channel through which aggregate demand management works is the heterogeneous labor market channel. There is a clear difference between the unemployment rates of low-skilled/low-wage and high-skilled/high-wage workers. Some of the disparity is determined by human capital investments but some of it depends on the distinctly different employment patterns that these two groups face (Figure 1). Individuals in low wage occupations tend to experience a vicious employment cycle - they are hired last and fired first, whereas the 
workers in high wage occupations enjoy a virtuous cycle of longer employment tenure, shorter spells of unemployment, and better re-employment opportunities. Therefore, hiring patterns throughout the business cycle ensure that lower skilled individuals do not build sufficient work experience to become more "employable" in the eyes of private employers.

Figure 1 Longer and deeper spells of unemployment for lower wage occupations ${ }^{2}$

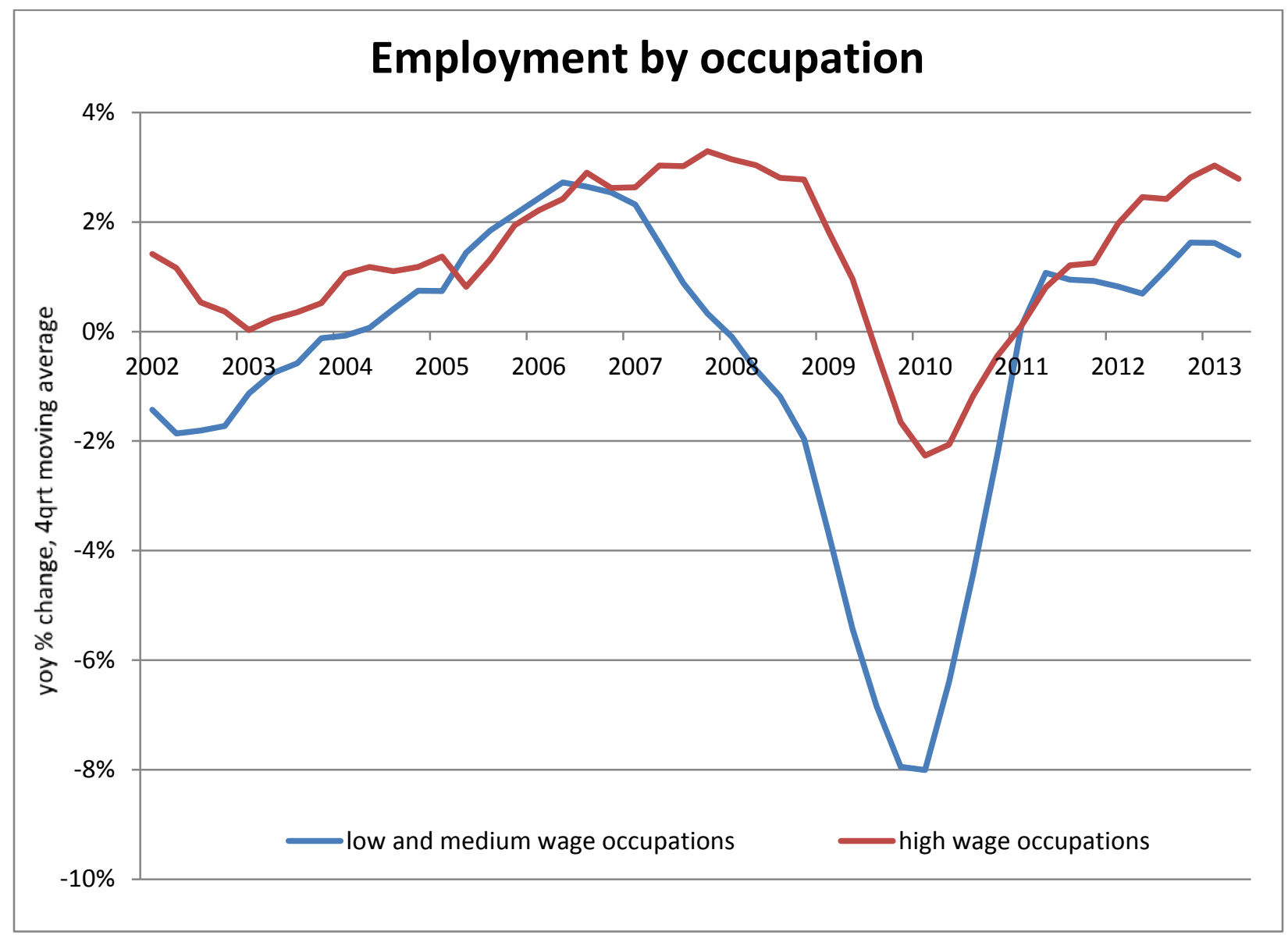

Source: author calculations based on $w w w . b l s . g o v$ data

As it is currently practiced, countercyclical government spending provides stabilization to GDP by reproducing the hiring behavior of private labor markets. In other words, government spending either provides income and subsidies to investors who tend to hire the more skilled first and the less skilled last, or government itself hires workers in this manner. An examination of the direct job creation effect of the American Recovery and Reinvestment Act of 2009 (Recovery

\footnotetext{
${ }^{2}$ The data considers low and medium occupations together due to the 'hollowing-out' effect in the labor market, whereby full time employment in high-medium wage occupations (i.e., middle-class jobs) has become a very small share of all occupations.
} 
Act), for example, confirms this finding (Tcherneva 2012a) and reveals that many of the recovery jobs were indeed high-skill, high-wage jobs, whereas few of them were targeted to those who experience the most precarious labor market conditions throughout the business cycle. Indeed only about half of one percent of total Recovery Act spending was allocated to direct training and employment for the hard-to-employ individuals ( $\$ 4.8$ billion out of a total budget of $\$ 840$ billion; see ibid.).

In other words, conventional fiscal fine-tuning measures ensure that when government increases its total demand for goods and services, it first improves the conditions of the skilled, employable, highly educated, and relatively highly-paid wage and salary workers, who normally experience comparatively fewer spells of unemployment and manage to build considerable job tenure. It is hoped that after those workers increase their own demand for products and services, the fiscal stimulus would trickle down to the less skilled and low-wage workers and, eventually, to the least skilled individuals at the bottom of the income distribution. This trickle-down mechanism never quite trickles down far enough to create job opportunities for all individuals willing and able to work, irrespective of their skill and education level. Furthermore, this policy itself creates more unequal within-labor income distribution.

This approach also cannot be counted on to produce full employment, because inflationary pressures kick in before the economy reaches full capacity utilization. This is because, as Keynes articulated back in 1936, the closer the economy is to full employment, the more any given increase in total spending results in greater price increases and incrementally smaller employment increases (Keynes [1936] 1964, p. 285). These inflationary pressures skew the income distribution and prompt policy makers to abandon the aggregate demand stimulus before full employment is reached.

\subsection{The New Consensus Demand-Side Trickle-Down Approach}

A different type of demand-side mechanism has been proposed in the New Consensus literature. Its transmission mechanism works through an expectations-augmented wealth effect channel and takes the form of either direct government spending or, preferably, the so-called "fiscal components of monetary policy" (Bernanke 2000). The return to fiscal policy effectiveness in the mainstream rests on a rejection of the Ricardian Equivalence Hypothesis (REH) in the case of non-Ricardian regimes (Leeper 1991, Sims 1994, Woodford 1995 and 1998). Recall that 
according to the REH, any windfall from government deficit spending does not boost private consumption or investment, because it is saved by rational agents in anticipation of higher future taxes to repay the deficit. By contrast, under non-Ricardian regimes (Woodford 1995), governments can deficit spend in the current period to stimulate economic growth, but without raising future taxes (and primary surpluses) to "pay" for them. These theoretical developments are largely associated with Woodford's Fiscal Theory of the Price Level (ibid.) and Bernanke's work on the 90s Japanese deflation (e.g., Bernanke 2000), where a "bond drop" or a "cash drop" (much like Friedman's helicopter drop of money) create net new financial assets in the hands of households and firms (i.e., a "crowding in" effect), which in turn increase their demand for goods and services (for details see Tcherneva 2010). The reason why some governments can afford to do so, according to Woodford and Bernanke, is because they do not face hard and binding financing constraints from the private sector. These non-Ricardian regimes are essentially sovereign currency regimes, where governments repay their debts by issuing more of their own liabilities (currency or reserves), either when the central bank directly finances government spending or when it purchases government bonds as a residual buyer. Under such regimes, the federal debt and deficit are technically forever sustainable, unlike in nations which have dollarized, committed to a fixed exchange rate, or joined a monetary union (ibid.). Thus fiscal policy in sovereign currency nations in the form of a "bond" or "money" drop can produce a wealth effect from the windfall of financial assets in the private sector, so long as expectations are properly anchored and private agents understand that the windfall is permanent. The increase in consumption and investment produces the requisite economic growth. Any employment effect is again a bi-product of this expectations-augmented wealth effect.

The manner in which such a money or bond drop occurs is important in evaluating the relative effectiveness of the fiscal transmission mechanism. Because of time inconsistency issues, the mainstream now believes that the wealth effect can be more effectively produced by central banks in coordination with the fiscal authorities, (i.e., through the fiscal components of monetary policy (Woodford 1998; Bernanke 2000, 2002)). Bernanke (2000) outlines several monetary policies that have fiscal components, two of which can generate significant wealth effects. The first works through the balance sheets of the financial sector and the second through household balance sheets. 
Aggressive non-traditional and permanent open market operations, Bernanke argues, can improve bank balance sheets by removing non-performing financial assets and replacing them with default risk-free reserves (ibid.). So long as the fiscal agent authorizes the central bank to purchase a wide range of private assets (e.g., commercial paper, mortgage-backed securities, credit default swaps and other), the financial sector would be recapitalized and resume lending activity. ${ }^{3}$ However, for any wealth effect from improved bank balance sheets to generate new economic activity, banks have to be willing to lend and investors have to be willing to borrow, invest and employ.

The second fiscal component of monetary policy is present when the central bank finances certain fiscal transfers such as the Clinton, G.W. Bush or Obama tax cuts. These components allow the central bank to "rain money" unilaterally on the population (Bernanke, 2000, p. 163). They too hinge on congressional authorization. The increase in household deposits that would result from the money-financed tax cut would encourage households to spend. But, according to mainstream logic, they would also induce banks to lend, as the increase in household deposits would be accompanied by a corresponding increase in bank reserves, which would then induce banks to lend to investors. Although in his writings Bernanke has expressed a preference for money-financed tax cuts over aggressive asset purchases, as a practical matter, he has relied heavily on the latter approach as Federal Reserve chairman, providing unprecedented subsidies to the banking sector through the various programs for the purchase of toxic assets.

To sum up, the policy objective according to the New Consensus model is to allow the monetary and fiscal policies to work in concert to provide new financial assets to the private sector (specifically to the financial sector) - assets that would reside in the banking sector and would generate the desired wealth effect. Any increase in net financial assets provided directly to the public (either through tax rebates or purchases of toxic financial assets) would generate a wealth effect through the above-mentioned expectations channel about future tax policy.

The New Consensus fiscal components of monetary policy also operate in a trickle-down fashion as any boost to demand for investment is supposed to trickle down from the government's demand for financial assets, and any demand for employment would trickle down from the resulting demand for investment. Once again, employment is at the very end of the

\footnotetext{
${ }^{3}$ Note that fiscal components of monetary policy are present when the central bank purchases assets, not when it lends against them.
} 
transmission mechanism, which is now much longer because it works not through direct demand for output and employment, but through bank balance sheets and the inducement to lend.

There are several problems with this approach to macroeconomic stabilization. First, as the current recession has demonstrated, the explosion of reserves in the banking system in 2008 and 2009 has not resulted in aggressive new lending to firms and households. Indeed the flawed assumption in the New Consensus transmission mechanism is that bank lending is reserve constrained, whereas as a matter of operational reality banks do not lend reserves (Fullwiler 2003). Instead, banks make loans to credit-worthy borrowers when conditions warrant lending and look for reserves only for payments-clearing and to meet reserve requirements after the loans have already been made. Banks will also refuse to make new loans if they are worried about repayment, no matter how many excess reserves they have, as expressly demonstrated by bank activity over the last five years. Therefore, the new fiscal policy stimulus channeled through the monetary authority has not generated the expected trickle-down effect from reserves to loans and from the financial to the real sector, nor has it generated the required wealth effect that would propel private consumption and investment forward to reduce the unemployment rate to desired levels. And even if this "money drop" policy managed to generate considerable economic activity, Bernanke (2012) has articulated that the policy would be discontinued well before true full employment is achieved in order to prevent the potential onset of inflation (Bernanke targets around 5.2 - $6 \%$ unemployment). The assumption that any government stimulus must be removed well before unemployment reaches its presumed NAIRU level is a hallmark of modern mainstream macroeconomic policy. The experience of the Great Recession has demonstrated that the assumptions behind the New Consensus transmission mechanism of a coordinated fiscalmonetary policy are flawed and that stabilizing the income shares of the financial sector relative to those of the real sector has not only failed to generate the requisite wealth effect, growth and employment, but has also worsened the income and wealth distribution at an unprecedented rate (Tcherneva 2012a, Saez 2012).

The conventional approaches to macroeconomic stabilization throughout the postwar era have decidedly failed to secure tight full employment, but over time they have also contributed to the erosion of the income distribution. An examination of average income growth during every postwar expansion (from trough to peak) and its distribution between the wealthiest $10 \%$ and bottom $90 \%$ of households reveals that income growth becomes more inequitably distributed 
with every subsequent expansion during the entire postwar period (Figure 2). Only during the 1950-53 expansion did the bottom 90\% capture all of the average income growth in the economy. Since then, the top $10 \%$ of households have been capturing greater and greater share of the income growth and, in the first two expansions of the $21^{\text {st }}$ century, they have captured all of the income growth. Note that income distribution still eroded during the "Golden Age" of American economy, at a time when the government heavily relied on conventional pump priming methods to stabilize the business cycle. With the advent of supply-side fiscal measures, income inequality worsened much faster, and in the age of New Consensus fiscal policy stabilization, the economy has witnessed the largest transfer of income to the top in American history (ibid).

Figure 2 Inequality worsens with every expansion in the postwar era

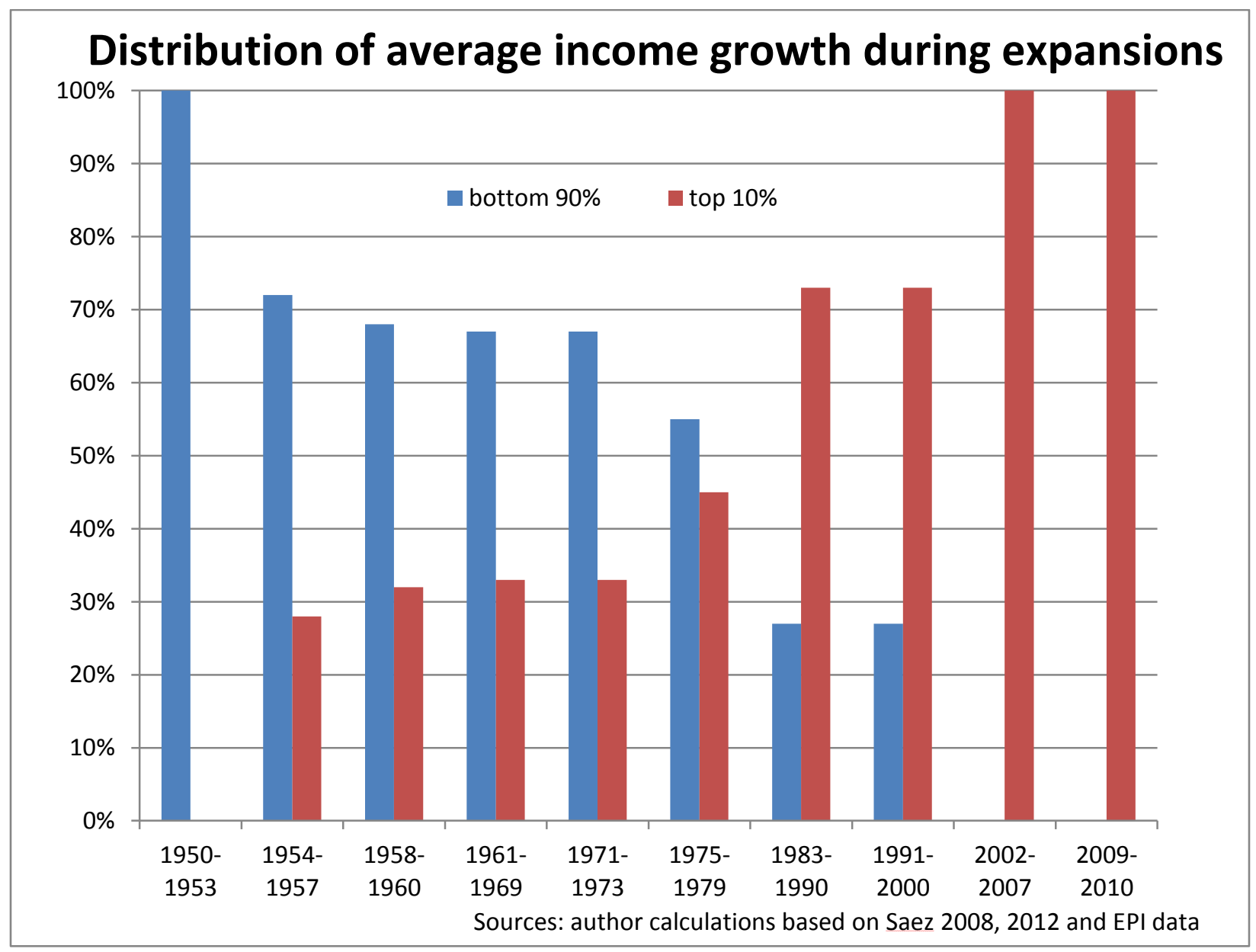




\section{THE ALTERNATIVE: A BOTTOM-UP APPROACH TO FISCAL POLICY}

The foregoing analysis presented several distinct problems with the two conventional demandside management approaches. Their transmission mechanisms work through improving rentier incomes, profits and high wages first and, thus, underwrite the very processes that create greater

income inequality between factor incomes, within labor income, and within capital income. They also fail to secure a close approximation to full employment because they work in a manner that improves the job prospects of those whom the private sector deems "more employable" first and those who are considered "less employable" last (if at all). The employment impact of progrowth/pro-investment policies is not only at the end of the transmission mechanism (i.e., it is a residual effect), but government policy itself reproduces the vicious and virtuous cycles of private sector hiring behavior.

We can now begin to identify some of the key features of a bottom-up policy that would ensure full employment and better income distribution. First, a genuinely effective countercyclical policy is one that, not only boosts spending when private sector demand collapses, but also expediently improves the income and employment condition of those at the very bottom of the income distribution. This can be accomplished if the orientation of policy in general is such that it targets the labor demand gap rather than the output gap (i.e., it aims to create jobs for all who are ready, willing and able to work). Labor demand targeting would be the focus of policy both in recessions and expansions. The government would devise a long run program, which countercyclically increases employment directly when private sector demand for workers falls short of what is necessary to provide employment for all. Importantly, the countercyclical government policy would not mimic the employment behavior of the private sector (thus competing for the high-wage, high-skill employable workers), but would instead offset it - providing employment opportunities where none exist to those who experience the most precarious labor market conditions, the longest spells of unemployment, and greatest difficulty reintegrating into the labor market. One of the aims of the countercyclical government policy would be to effectively break the vicious employment cycle for those at the bottom of the income distribution.

A bottom-up fiscal policy would be an explicitly pro-employment policy, which targets job creation directly and thus eliminates the possibility of a jobless recovery by definition. Such a policy would do so in a manner that improves, rather than erodes, the income distribution. 
Whereas the trickle-down demand management approaches to fiscal policy aim to close the output gap in the economy, the bottom-up approach aims to close the labor gap first. Instead of trying to produce a certain rate of growth and investment or level of reserves in the banking sector that would hopefully deliver the desired level of lending and investment and therefore employment, income distribution, and public goods provisioning, the bottom-up approach flips the objectives. It directly targets the unemployed, their incomes, and the very public goods needed by downwardly mobile communities and distressed and impoverished areas, leaving growth, investment, and the level of reserves to be determined as a consequence of such a policy. The direct approach has the important added benefit that it explicitly incorporates the needs of the environment along with those of the jobless and their communities. This approach also recognizes that full employment, better income distribution, and sustainable growth are complementary (not competing) policies.

Many Post-Keynesians and Institutionalists have critiqued the aggregate demand orientation of economic theory and fiscal policy. Joan Robinson rebuked the profession for its exclusive focus on total spending neglecting the structure of demand (Robinson 1972). Galbraith advocated aggregate demand management by government as essential for economic stability (Galbraith 1952) and explicitly envisioned a "planned" aggregate demand which directed spending to specific industries and products. These economists have embraced the original concern voiced by Keynes that economic theory and policy must reflect an understanding of structural economic changes (Keynes [1936] 1964). And whereas fiscal activism is generally endorsed by heterodox economists, many still tacitly accept the conventional pump-priming approach to government spending. The bottom-up approach specifically calls for targeting demand in a manner that accounts for the structural changes in the economy and with a specific focus of directly employing the unemployed, irrespective of whether they are new entrants in the labor market or structurally, cyclically, or seasonally unemployed.

There are a number of proposals that represent such a bottom-up orientation to fiscal policy: some focus on conventional public works that would absorb all of the unemployed over the long run (as in Keynes 1936), others include the Employer of Last Resort (Minsky 1986, Wray 1998), Buffer Stock Employment (Mitchell 1998), Public Service Employment (Harvey 1989), Job Guarantee (Ginsburg 1983), Green Jobs model (Forstater 2004), or the proposal for Full Employment through Social Entrepreneurship (Tcherneva 2012c). All programs share the 
common objective of securing true full employment over the long run by providing a voluntary employment opportunity for any unemployed individual, who is ready, willing and able to work, in a project that serves the public purpose. Though the institutional setup, design, management, and execution of these programs may differ, each of them aims to provide job opportunities for all, including those who are hard-to-employ, in a manner that enhances their skill, education and training. In addition, all proposals can serve as vehicles for achieving certain key socio-economic objectives such as alleviating poverty, urban blight, and environmental degradation and for renewing natural resources, restoring and enhancing public investments, and furthering the public purpose. The benefits of the bottom-up approach are numerous and their intellectual roots can be traced to the work of Keynes and Minsky.

\subsection{The Keynesian Roots of the Bottom-Up Approach}

This approach is based on an interpretation of Keynes's own policy approach to full employment (Tcherneva 2012b). Although it is well known that Keynes favored public works and the broader socialization of investment as policies for macroeconomic stability and full employment, the precise contours of his proposal have not been explicitly articulated by Keynes himself or subsequent authors. Indeed, James Meade actively urged Keynes to do so, but he responded that “another Keynes Plan might be one too many" (Skidelsky 2001, p. 270), referring to the first

Keynes Plan for a Clearing Union. A rereading of Keynes's policy writings, correspondence, and major works, unveils the blueprint of a rather specific Keynes Plan for full employment (Tcherneva 2012b). The core of this plan centers on direct employment, public goods provisioning and a careful targeting of demand. As Keynes himself put it during the buoyant interwar period "we are in more need today of a rightly distributed demand than of a greater aggregate demand" (Kregel 2008, Skidelsky 2001, p. 21). In other words, Keynes was committed to the goal of generating genuine full employment even in relatively prosperous times. Indeed, throughout all of his writings, he argued that the goal of full employment must not be abandoned once we approach it, and that there was no such thing as "natural" unemployment. Rereading his works from this vantage point reveals that fine-tuning through aggressive deficit spending is neither the Keynesian solution to macroeconomic stability, nor to the problem of unemployment. Indeed, because the two goals are inextricably linked, Keynes's proposal solved them simultaneously. Modern episodes of jobless recoveries or periods of stability that are 
nevertheless plagued by chronic unemployment are evidence of failed fiscal policies. A policy that is true to the original Keynesian prescriptions is not one of fine-tuning, but one of direct job creation via a permanent program for on-the-spot employment, where a "man-year of employment on the spot can be created immediately without obstacles" (Keynes 1982, p. 171).

There are clear theoretical, methodological and policy reasons why a bottom-up approach to fiscal policy that centers on direct hiring is superior to pump-priming in achieving true full employment and macroeconomic stability over the long run. Aggregate demand management has incorrectly become known as the "Keynesian solution" to crises and unemployment in large part due to the mistaken conflation between the concepts of effective and aggregate demand. For Keynes, employment equilibrium is a function of three key independent factors - the marginal efficiency of capital (MEC), the marginal propensity to consume (MPC), and the marginal efficiency of money (MEM). These are purely subjective factors, dependent on firms' expectations for the future, personal preferences, and the appetite for liquidity of the community as a whole. And since none of these factors is under the direct control of policy makers, fixing and keeping them at the full employment level of effective demand is impossible via a policy of fine-tuning overall government spending (see also Kregel 2008). Instead, full employment can be secured over the long run by direct means that would also permit policy makers to address structural changes as needed. Keynes intended for this "on-the-spot" employment approach to be implemented at all stages of the business cycle and to offer job and retraining opportunities to the cyclically, structurally, and long-term unemployed, as well as to new entrants in the labor force, part-time job seekers, or anyone else who has not found employment in the private sector (Keynes 1980, p. 357, Tcherneva 2012b).

A genuinely Keynesian program will achieve true full peacetime employment, by putting the unemployed individuals to work in jobs designed for the public purpose of "replanning the environment of our daily life..." (Keynes 1980, p. 270). Keynes argued that good public policies are not only driven by the intellectual conviction that full employment is indispensable and possible, but are also designed with imagination and cleverness in creating projects that are beneficial to the community as a whole:

The whole of the labor of the unemployed is available to increase the national wealth. It is crazy to believe that we shall ruin ourselves financially by trying to find means for using it and that safety lies in continuing to maintain idleness. (Keynes 1981, p. 881) 
The main task is producing first the intellectual conviction and then intellectually to devise the means. Insufficiency of cleverness, not of goodness, is the main trouble. (Keynes 1980, p. 384)

Some of the key aspects of the bottom-up approach à la Keynes are the following: (1) public works (or any other direct employment schemes) are not "depression solutions" and must not be discontinued near full employment, as this is precisely the time when private industry is less capable of absorbing any additional workers (Keynes 1982, p. 150); (2) the goal of the program is to provide jobs for all in projects that serve the public purpose. Keynes's policy was one of targeting the unemployed, not industry (though the two policies need not compete with each other); (3) modern output measures in terms of current or real prices do not account for the loss of labor as a result of changes in aggregate demand (Keynes 1980, p. 71) ; (4) potential output measures are especially flawed in assessing the full employment level of output (ibid., pp. 72-72) and must be calculated instead in terms of number of men and women who might be employed (ibid., pp. 280-307); (5) instead of closing the demand gap for output, Keynes specifically argued for closing the labor demand gap (ibid.); (6) the unemployed must be hired via direct means both in contractions and expansions, as well by taking the contract to the worker (Brown 1936); and (7) unemployment must not be used to fight inflation (Keynes 1980, p. 374).

Keynes envisioned fiscal policy in the form of direct job creation for three main reasons: (1) such an approach has the highest primary, secondary and induced employment-creation effects of any fiscal policy (see specifically the Macmillan committee deliberations (Keynes 1981, pp. 174-175)); (2) it can direct demand to the periphery of economic activity, including lagging urban or rural areas; and (3) it can be a useful institutional tool for the broader socialization of investment that would attain and maintain full employment over the long run. Public works are a preemptive measure - they do not wait until unemployment has considerably developed in order to address it. They are a long-term program of direct job creation and public investment, which ensures that the jobless are immediately absorbed in the public sector as they lose their private sector work. Aggregate demand management is a policy measure that is always "too late" (Keynes 1982, p. 394).

These are the broad contours of the original Keynesian recipe for fiscal policy for full employment and macroeconomic stability. They can serve as a guide for any Keynes-inspired fiscal policy proposal that is serious about achieving true full employment, long-term macroeconomic stabilization, better income distribution, and improved socio-economic 
outcomes. In this spirit, fiscal policy requires a fundamental reorientation if it is to align contemporary government stabilization policies with the objective of full employment. As already noted, the bottom-up approach to government spending meets this challenge by directly addressing the needs of the unemployed, the blight of distressed areas and communities, and the deficiency of public goods. Note that Keynes himself had a very tight definition to full employment, namely "less than $1 \%$ of peacetime unemployment... or the sort of levels of unemployment that the economy has been capable of achieving during wartime" (Keynes 1980, p. 303). This tight definition also underpins the bottom-up approach advanced herein, although as a practical matter the specific design, implementation, and execution of various bottom-up policies may result in somewhat higher unemployment rates, on the order of 2-3 percent of (mostly) frictional unemployment. This approach not only achieves as close an approximation to full employment as is practically possible, but it also provides an effective and sustainable method for improving the income distribution.

\subsection{Two Ways Of Improving The Income Distribution}

There are two methods for improving the income distribution through policy. One is to work within the existing structures that produce and reproduce certain factor income shares and to reallocate income through various income redistribution schemes after income has been earned and those shares have been determined. The other policy is to change the very way income is earned from the outset. The Keynesian targeted demand approach can do so by directly increasing and stabilizing the share of labor income in production. It also ensures that by employing the unemployed, it improves incomes at the bottom of the income distribution faster than incomes at the top, thus improving within labor-income distribution. As Minsky had argued, "instead of the demand for low wage workers trickling down from the demand for the high-wage workers, such a policy should result in increments of demand for present high wage workers 'bubbling up' from the demand for low wage workers” (Minsky 1968, p. 338). Such a policy, far from working through the prevailing structures that produce income inequality, will begin to transform them by stabilizing incomes and employment at the bottom by employing workers in the production of public goods and services. This latter aspect of the labor targeting approach can go a long way to reversing the tendency of the public sector to lag the private sector in providing the protective services that are required as economies expand. 
The existence of a direct job creation program obviously does not eliminate rentier incomes, which both Keynes and Minsky thought was necessary for a genuinely stable economy that produced a more equitable income distribution. But even in the presence of certain sources of rent income, the overall income distribution will be dramatically improved if fiscal policy is reoriented away from aggregate demand management and towards direct job creation. First, such an approach will foster strong labor force attachment. ${ }^{4}$ Second, augmenting the safety-net for the jobless (especially the long-term unemployed) by linking the provisioning of income to the provisioning of jobs in the social services sector would change the very way in which income is generated and earned, thereby improving the income distribution while fostering the social sector and the supply of public goods. Third, the bottom-up approach would go a long way towards reducing poverty and providing much needed social services. Minsky (1965) observed that the 1960s decline in poverty was largely due to the fall in unemployment and estimated that through a direct job creation program, poverty would be virtually eliminated (ibid.; Minsky 1968, p. 329). Today, for example, there are 37 million Americans, including 14 million children, who rely on food assistance - that is one in every eight people (Hunger Report 2010). Furthermore, 43.6 million Americans (one in seven people) live in poverty - the highest number in 51 years (DeNavas-Walt, Proctor, and Smith 2010). Pigeon and Wray (1998) have demonstrated that even during the booming Clinton economy, the pro-growth orientation of government spending did not trickle down to the bottom of the income distribution. Bell and Wray (2004) have updated Minsky's calculations to confirm that direct job creation is key for poverty alleviation.

Conventional fiscal policies are bankrupt from a moral and economic perspective. Aggregate demand management favors the "haves" over the "have-nots" (ibid.): it provides handouts to the needy as the "right thing to do" but offers no genuine employment opportunity that allows them to start climbing the economic ladder. Thus it is fundamentally demoralizing and inefficient. It fails to fix the economy in a way that provides sufficient number of jobs to all who want them. Instead, it pressures the unemployed and the poor to "reform themselves" and fosters invidious policies such as the 1996 welfare reform ${ }^{5}$, which produced a far more punitive program - one that requires the recipients to work, but does not guarantee a job opportunity. And

\footnotetext{
${ }^{4}$ Note that in the current crisis labor force participation has fallen to its lowest levels in four decades. Furthermore, unemployment is highly concentrated in different socio-economic groups and highly correlated with a broad range of socio-economic problems.

${ }^{5}$ Personal Responsibility and Work Opportunity Reconciliation Act of 1996
} 
indeed, welfare reform has failed to lift welfare recipients out of poverty (Peterson, Song, and Jones-DeWeever 2002; Turner, Danziger, and Seefeldt 2006). The manpower of the poor and the unemployed can be mobilized for the public purpose irrespective of their skill level, which in turn will be upgraded by the very work experience and educational programs that the program would offer.

The current orientation of fiscal policy aims to close the demand gap for output. Yet modern measures of current output do not account for the loss of labor that occurs from shifts in aggregate demand, either because of changes in economic activity or due to automation. Furthermore any measure of potential output is fundamentally flawed - Keynes (1980, p. 72) called it "an impostor" - as it cannot adequately reflect the maximum capacity of an economy to produce even for very brief period of time. The bottom-up approach to fiscal policy does not attempt to close an ill-defined demand gap for output, which does not explicitly consider the shifts in labor demand due to shifts in aggregate demand. Instead it moves policy making away from general demand-side measures to very specific direct employment and investment initiatives that close the demand gap for labor both in recessions and in expansions. It relies on employment initiatives by the public and non-profit bodies to create direct employment for all who want to work but have not found suitable private sector employment at a base living wage. The bottom-up approach puts employment creation at the beginning of the transmission mechanism and makes jobless recoveries a thing of the past. It targets the hard-to-employ individuals in distressed areas and communities in a manner that breaks the vicious employment cycle they experience in the private sector. By moving away from the pro-investment, progrowth, pump-priming orientation of policy, fiscal stabilization efforts will no longer contribute to the erosion of the income distribution that takes place in expansions under conventional stabilization methods. Fiscal policy that guarantees a floor to labor demand over the long run, would also improve income inequality by guaranteeing incomes from wages at the bottom of the income distribution. Importantly, by putting the unemployed to work for the public purpose, fiscal policy directly matches the idle resources with the unfilled needs. 


\section{CONCLUSION}

Although the profession has long abandoned the goal of achieving and preserving full employment, this objective is as important as ever and within policy reach so long as we heed the original Keynesian message. Minsky's early critiques of aggregate demand management and his policy proposals fit squarely in the above-discussed reinterpretation of Keynes's fiscal policy approach to full employment, and reinforce the case presented herein for reorienting policy away from the two contemporary demand-side trickle-down measures and towards a bottom-up approach that is based on labor-demand targeting. Full employment, environmental sustainability, and public stewardship are sensible cardinal measures for fiscal policy effectiveness and a carefully designed permanent program for direct employment of the unemployed can serve as an important institutional vehicle that can deliver long-term full employment, macroeconomic stability, and shared prosperity. 


\section{REFERENCES}

Barro, R. J. 1974. “Are Government Bonds Net Wealth?” Journal of Political Economy. 82 (6): 1095-1117.

Bell, S. and L. R. Wray. 2004. “The War on Poverty after 40 Years: A Minskian Assessment.” Levy Institute Public Policy Brief 78: 7-29.

Bernanke, B.S. 2000. “Japanese Monetary Policy: A Case of Self-Induced Paralysis?” In Japan's Financial Crisis and its Parallels to U.S. Experience, R. Mikitani and A. Posen (eds.), Washington, DC: Institute for International Economics.

. 2002. "Deflation: Making Sure 'It' Doesn't Happen Here.” Remarks before the National Economists Club, Washington, D.C., November 21.

. 2012. "The Economic Outlook and the Federal Budget Situation." Remarks before the Committee on the Budget, U.S. House of Representatives, Washington, D.C. February 2.

Blinder, A. 2004. "The Case against the Case against Discretionary Fiscal Policy." CEPS Working Paper No. 100, Princeton University Center for Economic Policy Studies.

Brown. E. 1936. "Defense Programmes-Labor Issues Involved." Cabinet Paper \#57, Cabinet Office Paper Series 24, Volume 260.

Buiter, W.H., Persson, T., and Minford, P. 1985. "A Guide to Public Sector Debt and Deficits." Economic Policy, 1: 14-79.

Canton, V. A., D. H. Joines, and A. B. Laffer. 1983. Foundations of Supply-Side Economics: Theory and Evidence, New York: Academic Press.

DeNavas-Walt, C., B. D. Proctor, and J. C. Smith. 2010. Income, Poverty, and Health Insurance Coverage in the United States: 2009. U.S. Census Bureau Current Population Report P60-238, Washington, D.C.: U.S. Government Printing Office.

Forstater, M. 2004 "Green Jobs: Addressing the Critical Issues Surrounding the Environment, Workplace and Employment." International Journal of Environment, Workplace and Employment, 1(1): 53-61.

Fullwiler, Scott T. 2003. "Timeliness and the Fed's Daily Tactics." Journal of Economic Issues, 37 (4), 851-880.

Galbraith, J. K. 1952. American Capitalism, Boston: Houghton Mifflin Company. 1958. The Affluent Society, Boston: Houghton Mifflin Company. 
Ginsburg, H. 1983. Full Employment and Public Policy: The United States and Sweden, Lexington, MA: Lexington Books

Harvey, P. 1989. Securing the Right to Employment: Social Welfare Policy and the Unemployed in the United States, Princeton, NJ: Princeton University Press.

Henderson, D. 1989. “Are We All Supply-Siders Now?” Contemporary Policy Issues, October, 7(4): 116-128.

Hunger Report. 2010. Hunger in America, National Report prepared for Feeding America (January), http://feedingamerica.issuelab.org/research/listing/hunger_in_america_2010_national_rep ort (accessed May 12, 2012).

Keynes, J. M. [1936] 1964. The General Theory of Employment, Interest, and Money, New York: Harcourt-Brace \& World, Inc.

-1980. Activities 1940-46. Shaping the Post-War World: Employment and Commodities. Volume XXVII of Collected Works, edited by Donald Moggridge, London: Macmillan.

-1981. Activities 1929-31. Rethinking Employment and Unemployment Policies. Volume XX of Collected Works, edited by Donald Moggridge, London: Macmillan.

-1982. Activities 1931-39. World Crises and Policies in Britain and America. Volume XXI of Collected Works, edited by Donald Moggridge, London: Macmillan.

Kalecki, M. 1954. Theory of Economic Dynamics: An Essay on Cyclical and Long- Run Changes in Capitalist Economy, London: George Allen and Unwin.

Kregel, J. A. 2008. “The Continuing Policy Relevance of Keynes's General Theory.” In M. Forstater and L. R. Wray (eds.) Keynes for the 21st Century: The Continuing Relevance of The General Theory, London: Macmillan.

Leeper, E. 1991. 'Equilibria under 'Active' and 'Passive' Monetary and Fiscal Policies." Journal of Monetary Economics, 27: 129-47.

Lucas, R. 1972. "Expectations and the Neutrality of Money." Journal of Economic Theory 4(2): $103-124$.

Minsky, H. P. 1965. "The Role of Employment Policy." in Poverty in America, edited by Margaret S. Gordon, 175-200, San Francisco: Chandler Publishing Company.

- 1968. "Effects of Shifts in Aggregate Demand on Income Distribution." American Journal of Agricultural Economics, 50(2): 328-339. 
—. 1973. "The Strategy of Economic Policy and Income Distribution." The Annals of the American Academy of Political and Social Science 409: 92-101.

—. 1986. Stabilizing an Unstable Economy, New Haven: Yale University Press.

Mitchell, W. F. 1998. "The Buffer Stock Employment Model and the NAIRU: The Path to Full Employment." Journal of Economic Issues, 32(June): 547-556.

Okun, A. 1962. "Potential Output: Its Measurement and Significance." In Proceedings of the Business and Economic Statistics Section, American Statistical Society. Washington, D.C.: American Statistical Association.

Peterson, J., X. Song, and A. Jones-DeWeever. 2002. "Life after Welfare Reform: Low-Income Single Parent Families, Pre- and Post-TANF." Institute for Women's Policy Research Publication \#D446.

Pigeon, M.-A. and L. R. Wray. 1998. "Did the Clinton Rising Tide Lift All Boats." Levy Institute Public Policy Brief 45: 7-36.

Robinson, J. 1972. "The Second Crisis of Economic Theory." American Economic Review, 62(1): 1-10.

Saez, E. 2012. "Striking It Richer: The Evolution of Top Incomes in the United States." Stanford Center for the Study of Poverty and Inequality, (updated with 2009 and 2010 estimates). Original methodology in Saez, E. and Picketty, T. (2003): 'Income Inequality in the United States, 1913-1998,' Quarterly Journal of Economics, 118(1): 1-39.

Sargent, T. J., Wallace, N. 1973. "The Stability of Models of Money and Growth with Perfect Foresight." Econometrica, 41(6): 1043-1048.

Sims, C. 1994. "A Simple Model for the Determination of the Price Level and the Interaction of Monetary and Fiscal Policy." Economic Theory, 4(3): 381-99.

Skidelsky, R. 2001. John Maynard Keynes, Volume Three: Fighting for Britain 1937-1946. London: Macmillan.

Snowdon, B. and H. R. Vane. 2005. Modern Macroeconomics: Its Origins, Development and Current State, Cheltenham: Edward Elgar.

Tcherneva, P. R. 2012a. "The Role of Fiscal Policy: Lessons from Stabilization Efforts in the U.S. During the Great Recession.” International Journal of Political Economy, (forthcoming).

_. 2012b. "On-the-spot Employment: Keynes's Approach to Full Employment and Economic Transformation.” Review of Social Economy, 70 (1): 57-80. 
—. 2012c. "Full Employment through Social Entrepreneurship: the Non-Profit Model for Implementing a Job Guarantee." Policy Note 2012/1, Levy Economics Institute, Annandale-on-Hudson, March.

- 2010. "Fiscal Policy: The Wrench in the New Economic Consensus." International Journal of Political Economy, Fall, 39(3): 24-44.

Turner, L. J., S. Danziger, and K. S. Seefeldt. 2006. "Failing the Transition from Welfare to Work: Women Chronically Disconnected from Employment and Cash Welfare." Social Science Quarterly, 87 (2): 227-249.

Woodford, M. 1995. "Price-level Determinacy without Control of a Monetary Aggregate." Carnegie-Rochester Conference Series on Public Policy, 43 (December): 1-46. . 1998. "Public Debt and the Price Level." Princeton University Working Paper, July. http://www.columbia.edu/ mw2230/BOE.pdf.

. 2000. "Fiscal Requirements for Price Stability." Princeton University Working Paper, October. http://www.columbia.edu/ mw2230/jmcb.pdf, abridged version published as Woodford, M. (2001): 'Fiscal Requirements for Price Stability,' Journal of Money, Credit and Banking, 33(3): 669-728.

. 2003. Interest and Prices: Foundations of a Theory of Monetary Policy, Princeton, NJ: Princeton University Press.

Wren-Lewis, S. 2000. "The Limits to Discretionary Fiscal Stabilization Policy.” Oxford Review of Economic Policy, 16(4): 92-105.

Wray, L. R. 1998. Understanding Modern Money: The Key to Full Employment and Price Stability, Cheltenham: Edward Elgar. 